\title{
Survey of Wintering Eurasian Woodcock in Western Europe
}

DAVID GONÇALVES, ${ }^{1}$ CIBIO-InBIO, Centro de Investigação em Biodiversidade e Recursos Genéticos, Universidade do Porto, Campus Agrário de Vairão, 4485-661 Vairão, Portugal and Departamento de Biologia, Faculdade de Ciências, Universidade do Porto, R. Campo Alegre s/n, 4169-0o7 Porto, Portugal

TIAGO M. RODRIGUES, Departamento de Biologia, Faculdade de Ciências, Universidade do Porto, R. Campo Alegre $s / n, 4169-007$ Porto, Portugal and Direção Regional dos Recursos Florestais, Rua do Contador, 23, 9500-050 Ponta Delgada, Portugal

PAOLO PENNACCHINI, Féderation des Associations Nationales des Bécassiers du Palearctique Occidental (FANBPO), Via Fausto Vagnetti 12, 52031 Anghiari, Italy

JEAN-PIERRE LEPETIT, Club National des Bécassiers (CNB), 3, Allée des chénes, 87220 Feytiat, France

LARRY TAAFFE, The National Woodcock Association of Ireland (NWAOI), Effoldstown House, Lusk, Co. Dublin, Ireland

MARCO TUTI, Beccacciai d'Italia (BDI), Clemente Rebora 14 - 73100 Lecce, Italy

BRUNO MEUNIER, Club National des Bécassiers (CNB), 105, Rue Louis Pergaud, Villeneuve, 16430 Champniers, France

JEAN-PIERRE CAMPANA, ${ }^{2}$ Club National des Bécassiers (CNB), 8, Impasse des Bois, La Granje À Robin, 17770 Aumagne, France

GIANLUIGI GREGORI, Club della Beccaccia (CDB), Loc. Morani di sotto, 22 - 6104o Mercatello sul Metauro (PU), Italy

ALBERTO PELLEGRINI, Club della Beccaccia (CDB), Loc. Morani di sotto, 22 - 61040 Mercatello sul Metauro (PU), Italy

GIUSEPPE RAHO, Beccacciai d'Italia (BDI), Clemente Rebora 14 - 73100 Lecce, Italy

PAUL DUCHEIN, Association Suisse des Bécassiers (ASB), Planafaye 118, CH - 1752 Villars sur Glâne, Switzerland

COLIN TROTMAN, Welsh Woodcock Club (WWC), Department of Adult Continuing Education (DACE), Keir Hardie Building, Swansea University, Singleton Park, Swansea, SA2 8PP, Wales, UK

MIGUEL MINONDO, Club de Cazadores de Becada (CCB), Avenida Schulz 8, $4^{\circ}$ Dcha. 33208 Gijón, Spain

DERMOT FITZGERALD, ${ }^{2}$ The National Woodcock Association of Ireland (NWAOI), Effoldstown House, Lusk, Co. Dublin, Ireland

ANDRÉ VERDE, Associação Nacional de Caçadores de Galinholas (ANCG), Largo das Tílias, 4, 490o-o12, Afife, Portugal

GERARD AUROUSSEAU, Club National des Bécassiers (CNB), "villa KILUMA” 771, chemin de Fontmerie, o6250 Mougins, France

1 email: drgoncal@fc.up.pt

2 deceased 
FELIPE DÍEZ, Club de Cazadores de Becada (CCB), Avenida Schulz 8, $4^{\circ}$ Dcha. 33208 Gijón, Spain

KÉVIN LE-REST, Office national de la chasse et de la faune sauvage (ONCFS), Parc d'Affaires La Rivière, 8 Bd Albert Einstein, Bat. B - CS 42355, 44323 Nantes Cedex 3, France

YVES FERRAND, Office national de la chasse et de la faune sauvage (ONCFS), Parc d'Affaires La Rivière, 8 Bd Albert Einstein, Bat. B - CS 42355, 44323 Nantes Cedex 3, France

ABSTRACT The Eurasian woodcock (Scolopax rusticola) is a mostly migratory wader (Charadriiformes) that is broadly distributed across the Palearctic. This species winters in or migrates through all European countries and is an important quarry species in many of them. Sustainable management of the species requires information regarding abundance and demographic parameters to be collected regularly. This is a complex task given that different phases of its annual life cycle occur in different countries and, due to the species' secretive behavior, Eurasian woodcock populations cannot be properly evaluated by common bird-census techniques. In Europe, woodcock hunters from different countries have joined in the Federation of Western Palearctic Woodcock Associations (FANBPO), collecting data on hunting activity that can be used to annually evaluate relative abundance and demographic parameters. To investigate variation in Eurasian woodcock relative abundance during and between hunting seasons, we fitted generalized additive mixed models (GAMMs) to data collected in France, Spain, and Portugal (Franco-Iberian region; 2006-2007 to 2015-2016) to analyze the variation in the number of different Eurasian woodcock seen per hunting trip. For these countries and for Switzerland, Italy, Ireland, and Wales, we also analyzed demographic parameters (the ratios of female:male and juvenile:adult) from bagged birds. In the Franco-Iberian region the relative abundance during the autumn-winter period increased from September to the beginning of December, and remained high thereafter with a slight decrease until the end of February; in the last 10 years, relative abundance has remained stable during autumn migration and winter. The sex ratio remained stable in the Swiss-Franco-Iberian and Swiss-Italian regions, but the former had a higher proportion of females. The age ratio varied among hunting seasons and regions. This research is an example of the effective use of data collected through citizen science that aims to maintain a favorable conservation status of the Eurasian woodcock while allowing a rational use of its populations via sustainable and controlled hunting.

Proceedings of the American Woodcock Symposium 11: 240-251

KEY WORDS: relative abundance estimation, breeding success estimation, Eurasian woodcock, hunting, Scolopax rusticola, sex ratio estimation, survey, western Europe, wintering

The Eurasian woodcock (Scolopax rusticola) is a mostly migratory wader (Charadriiformes), widely distributed in the Palearctic (Ferrand and Gossmann 2001, Van Gils et al. 2015), with sedentary populations on the Atlantic islands (Azores, Madeira, and Canaries) and in some southwestern maritime countries (Snow and Perrins 1998; Fig. 1). The Eurasian woodcock that winter in Europe mainly originate from breeding areas in the northern, eastern, central, and parts of western Europe, and from western Siberia (Hoodless and Coulson 1994; Gossmann et al. 2000; Bauthian et al. 2007; Hobson et al. 2013a,b; Arizaga et al. 2014). Across this region the Eurasian woodcock population is estimated to number c.10-26 million individuals, the majority of which winter in western and southern Europe and northern Africa (Nagy et al. 2015, Wetlands International 2017). The European population is estimated at 13.8-17.4 million mature individuals and the population in the $\mathrm{EU}_{27}$ (European Union 27 member states; 1 January 2007-30 June 2013) is estimated at 1.5-2.9 million mature individuals (BirdLife International 2015). Due to the secretive behavior of the species, these estimates are mostly based on specialists' opinions rather than on objective data collected in the field. The exceptions are the British Isles and France, where the breeding population is estimated based on counts of roding birds (Hoodless et al. 2008, Heward et al. 2015, Ferrand et al. 2008).

Currently, the Eurasian woodcock's global conservation status is evaluated as Least Concern (LC; Birdlife International 2016). The only regional assessment available on trend concerns Europe, where the population trend appears to be stable. Within the EU27, the population size is estimated to be decreasing but by $<25 \%$ in 18.9 years ( 3 generations), and is thus evaluated as LC (BirdLife International 2015). The main factors that negatively affect the population within its breeding range seem to be the increased area of conifer plantations, which typically offer low diversity of age and stand type and are poor in shrub cover, and the increasing average age of woodland (Ferrand 
and Gossmann 2001, 2009b; Heward et al. 2015). Outside the breeding season, negative factors are the disappearance of permanent grasslands and the intensification of agricultural practices (e.g., the destruction of hedges, decreases in the number of permanent grazed meadows, and the impoverishment of soil fauna as a result of plowing and chemical application) (Ferrand and Gossmann 2001, $2009 b$; Duriez et al. 2005b). In addition to habitat changes, Eurasian woodcock are hunted in most European countries during the autumn migration and wintering periods, with the largest numbers taken in Greece (c. 1 million), France (c. 740,000), Ireland (c. 125,000), United Kingdom (c. 125,000), Italy (105,000), and Spain $(35,000)$ (Hirschfeld and Heyd 2005, Ferrand et al. 2017). Spring hunting still occurs in Russia, taking annually c. 166,000-213,000 individuals (Blokhin et al. 2015). With the exception of countries with good monitoring systems (e.g., France), some of these values are rough estimates.

The management of game species must be based on a strong scientific knowledge of their biology and ecology and on information regularly collected from their populations, especially regarding abundance and demography. For a sedentary species or population, the entire annual life cycle can be followed in the same area, but for migrants like the Eurasian woodcock, different phases of the annual life cycle occur in different areas, encompassing different countries, and thus different policies making their management a complex task.

The Eurasian woodcock is a solitary, elusive, and cryptic species. It is among those species that are not effectively evaluated by common bird-census techniques and that require the application of specific census methods to evaluate their abundance (Ferrand 1993, Hoodless et al. 2008). Hunting activity has been demonstrated to be useful in providing data to annually evaluate relative abundance and demographic parameters (Fadat 1979; Ferrand et al. 2006, 2008, 2010; Faragó et al. 2013; Rodrigues et. al. 2013; Guzmán and Arroyo 2015; Boidot et al. 2015; Christensen et al. 2017). An index of Eurasian woodcock abundance estimated from hunting trip data strongly correlates with another index of abundance obtained from nocturnal banding sessions, and is considered a valid approach to evaluated winter abundance variation (Ferrand et al. 2006, 2008, 2010). Hunting activity also can give crucial information on autumn migration and winter phenology, information important in evaluating the movements of the

birds, including their response to extreme weather conditions and the adequacy of placement and duration of hunting seasons.

In Europe, woodcock hunting associations from different countries encourage their affiliates to collect data, which can be used to monitor the trend and breeding success of the species. However, until now the analysis of these data has mainly been done at the country level (Rodrigues et al. 2013, Christensen and Asferg 2016, Meunier et al. 2016). These hunting associations are joined in the Féderation des Associations Nationales des Bécassiers du Palearctique Occidental (FANBPO, Federation Western Palearctic Woodcock Associations), which facilitates their cooperation. Founded in 2003, FANBPO presently joins c. 4,00o French (Club National des Bécassiers, CNB), c.1,00o Spanish (Club de Cazadores de Becada, CCB), c. 1,00o Italians (Club della Beccaccia, CDB, and Beccacciai d'Italia, BDI), 300 Swiss (Association Suisse des Bécassiers, ASB), c. 100 Portuguese (Associação Nacional de Cacadores de Galinholas, ANCG), c. 250 Irish (The National Woodcock Association of Ireland, NWAOI), and c. 50 Welsh (Welsh Woodcock Club, WWC) woodcock hunters (Fig. 1).

In this study we use data collected by FANBPO members to: 1) describe autumn migration and winter phenology of Eurasian woodcock in southwestern Europe; 2) evaluate trends of wintering Eurasian woodcock populations; and 3) make inferences regarding variation in rela- 
tive abundance and demographic parameters among hunting seasons. With these analyses, we aim to illustrate the importance of international cooperation for sustainable management of a migratory game species.

\section{Study Area}

During the breeding season in continental Europe, Eurasian woodcock prefer a mosaic of woodland types and ages and utilize broad-leaved, mixed, and coniferous woodland (Cramp and Simmons 1983; Hirons 1987, 1988a; Hirons and Johnson 1987; Ferrand 1989). In winter, their habitat requirements are less specific, and include mainly woodlands and hedges during the day and fields and meadows at night (Cramp and Simmons 1983; Hirons and Bickford-Smith 1983; Wilson 1983; Gossmann et al. 1988; Duriez et al. 2005a,b).

We analyzed data collected by FANBPO members during woodcock hunting in Portugal, Spain, France, Italy, Switzerland, Ireland, and Wales. Banding studies and isotope analysis suggest that Eurasian woodcock migrating through or wintering in these countries come from different regions of the species breeding range and thus may belong to different populations. Accordingly, for analysis, we organized data by 3 major regions: 1) Swiss-Franco-Iberian, a region that includes the cantons of Romandie in Switzerland (close to France), France, Spain, and Portugal, and represents a wintering area for birds coming mostly from east-central Europe and the Baltic region (Gossmann et al. 2000; Bauthian et al. 2007; Guzmán et al. 2011; Hobson et al. 2013a,b; Arizaga et al. 2014). 2) The Swiss-Italian region, which includes the canton of Ticino, in Switzerland (close to Italy), and Italy; this is probably part of the wintering area of Eurasian woodcock that bred in central Europe and Belarus (Gossmann et al. 2000). 3) The British Isles, including Ireland and Wales, where a significant number of Scandinavian and northwestern Russia Eurasian woodcock tend to winter (Hoodless and Coulson 1994, Hoodless et al. 2013).

\section{Methods}

\section{RELATIVE ABUNDANCE}

Data collection Hunters collected data during woodcock hunting trips in hunting seasons from 2006-2007 to 2015-2016, in France (since 2006-2007), Spain (since 2006-2007), and Portugal (since 2009-2010). For each hunting trip, they recorded the date, location, duration, and number of different Eurasian woodcock seen. Hunters reported this information to each club's or association's scientific committee in pre-formatted forms, on paper or online.

Hunting seasons vary among these countries in start and end dates, the number of hunting days permitted, and the number of Eurasian woodcock that may be shot, although the hunting season usually spans from September or October to January or February (Appendix A). The hunting process used for Eurasian woodcock is usually the same: Eurasian woodcock are found by pointing dogs and shot by the hunter. We considered for analysis only data collected from hunting that occurred between September and February and that used pointing dogs.

Analysis To investigate variation in Eurasian woodcock relative abundance during and between hunting seasons, we used $m g c v$ and poptrend R packages (Wood 2011, Knape 2016, R Core Team 2016) to fit generalized additive mixed models (GAMMs) with negative binomial errors and to visualize fits, respectively. All models included log of duration of each hunting trip (i.e., sampling effort) as an offset, and a 2-dimensional smoother for geographical coordinates of centroids of each region where hunting trips took place, to account for spatial auto-correlation (Zuur 2012). Because the precision of localities of each
Table 1. Summary of the generalized additive mixed models (GAMMs) for the variation in relative abundance of Eurasian woodcock (Scolopax rusticola) in southwestern Europe (France, Spain, and Portugal; hunting seasons 2006-2007 to 2015-2016) analyzing the species Phenology, between September and February, and Trends, between hunting seasons, for all data, migration period, and wintering period. Chi-square values, $P$-values and estimated degrees of freedom (EDF) are listed for each term included in the models. For each model the deviance explained (\%) is presented.

\begin{tabular}{|c|c|c|c|c|c|c|}
\hline & & Season & Decade & Day & Lat, Long & $\begin{array}{c}\text { Deviance } \\
\text { explained (\%) }\end{array}$ \\
\hline & & 175.2 & $9524 \cdot 3$ & & 47178.8 & \\
\hline Phenol & ogy & $<0.001$ & $<0.001$ & - & $<0.001$ & 26.4 \\
\hline & & $(0.99)$ & $(14.12)$ & & $(23.30)$ & \\
\hline & & 6.1 , & & 9660.8 & 47566.1 & \\
\hline & All & 0.042 & - & $<0.001$ & $<0.001$ & 26.9 \\
\hline & & $(2.49)$ & & $(8.90)$ & $(23.30)$ & \\
\hline & & 2.7 & & 9753.9 & 28263.0 & \\
\hline Trend & Migration & 0.210 & - & $<0.001$ & $<0.001$ & 27.7 \\
\hline & & $(1.27)$ & & & & \\
\hline & & 3.2 & & 119.2, & 20535.2 & \\
\hline & Winter & 0.160 & - & $<0.001$ & $<0.001$ & 26.9 \\
\hline & & & & $(4.73)$ & $(23.11)$ & \\
\hline
\end{tabular}


hunting trip varied, we considered coordinates of centroids of 91 French departments (mean area \pm SE: 5,925.0 $\left.\pm 168.1 \mathrm{~km}^{2}\right)$, 40 Spanish provinces $\left(10,114.5 \pm 791.6 \mathrm{~km}^{2}\right)$, and 18 Portuguese districts $\left(4,941.4 \pm 499.0 \mathrm{~km}^{2}\right)$.

First, to describe autumn migration and wintering phenology of Eurasian woodcock in southwestern Europe, we modeled number of different Eurasian woodcock seen through the hunting season, according to "decade" (period of 10 days of each month), with hunting season as a covariate modelled as a smooth term with automatic selection of df (Knape 2016).

Second, we evaluated variation in relative abundance between hunting seasons by including region and day of hunting season as covariates, modelled as smooth terms with automatic selection of $\mathrm{df}$. We built 3 models with $10 \mathrm{df}$ with data from the: 1 ) entire hunting season (the first decade of September to the third decade of February); 2) migratory period (from the first decade of October to the second decade of December); 3) wintering period (from the third decade of December to the second decade of February).

The first day of the hunting season was always considered as 1 September and, therefore, for each hunting trip, the day of the hunting season was determined as the number of days since 1 September.

Table 2. Variation among hunting seasons (2006-2007 to 2015-2016) in the sex ratio (females/male) of Eurasian woodcock (Scolopax rusticola) hunting bags in the Swiss-Franco-Iberian and Swiss-Italian regions. n: sample size; Chi-square test $\left(\chi^{2}\right)$ results comparing frequencies of sexes between regions (all comparisons were significant at $P<0.001$ ).

\begin{tabular}{|c|c|c|c|c|c|}
\hline \multirow{3}{*}{$\begin{array}{l}\text { Hunting } \\
\text { season }\end{array}$} & \multicolumn{4}{|c|}{ Region } & \multirow[b]{3}{*}{$\chi^{2}$} \\
\hline & \multicolumn{2}{|c|}{$\begin{array}{c}\text { Swiss-Franco-Iberian } \\
\text { Switzerland }^{\mathrm{a}} \text { France, }^{\text {, }} \\
\text { Spain, Portugal }^{\mathrm{b}}\end{array}$} & \multicolumn{2}{|c|}{$\begin{array}{c}\text { Swiss-Italian } \\
\text { Switzerland }{ }^{c}, \text { Italy }\end{array}$} & \\
\hline & Females:male & $n$ & Females:male & $n$ & \\
\hline $2006-2007$ & 1.54 & 2,233 & & & \\
\hline $2007-2008$ & 1.54 & 2,543 & & & \\
\hline 2008-2009 & 1.59 & 2,516 & & & \\
\hline $2009-2010$ & 1.60 & 2,727 & 0.94 & 322 & 20.70 \\
\hline $2010-2011$ & 1.52 & 1,929 & 1.06 & 411 & 11.07 \\
\hline $2011-2012$ & 1.53 & 2,187 & 1.02 & 617 & 20.14 \\
\hline $2012-2013$ & 1.57 & 2,335 & 1.19 & 1,244 & $15 \cdot 36$ \\
\hline $2013-2014$ & 1.52 & 2,370 & 1.11 & 1,695 & 23.37 \\
\hline $2014-2015$ & 1.43 & 2,088 & 1.07 & 2,235 & 21.94 \\
\hline $2015-2016$ & 1.45 & 1,950 & 1.12 & 2,202 & 16.47 \\
\hline Total & & 22,878 & & 8,726 & \\
\hline
\end{tabular}

a only cantons from Romandie; ${ }^{b}$ since $2009-2010 ;{ }^{c}$ only Ticino

\section{DEMOGRAPHY}

Data collection Sex and age, or age only, were determined for Eurasian woodcock shot in Switzerland (since 20082009), Italy (since 2010-2011), Ireland (since 2008-2009), Wales (since 2012-2013), France (since 2006-2007), Spain (since 2006-2007), and Portugal (since 2009-2010; see Tables 1 and 2). Eurasian woodcock are not sexually dimorphic so birds were sexed by gonad examination after dissection, primarily by hunters. Trained "wing readers" determined age class [juvenile ( $<1$ year old) or adult ( $>1$ year old)] by wing examination, according to Ferrand and Gossmann (2009a).

Additionally, we consider published data from Denmark, where Eurasian woodcock wings have been collected since the 1970s (Clausager 1974, Christensen 2017). This country is located upstream in a flyway that, probably, mostly concerns the British Isles and the Swiss-Franco-Iberian regions (Harradine 1983, 1988; Ferrand et al. 2008). Therefore, the annual Eurasian woodcock age ratio on the Danish hunting bag is considered to most closely correspond to breeding success of Eurasian woodcock in that region of Europe (Fadat 1988, 1995; Harradine 1983, 1988, Ferrand et al. 2008).

Analysis We organized data based on the major regions described previously. We investigated variation in the proportions of sex- and age-classes among hunting seasons based on chi-square tests and conducted statistical tests with $\alpha=0.05$.

\section{Results}

\section{RELATIVE ABUNDANCE}

We analyzed a total of 356,837 reports of hunting trips from France, Spain, and Portugal, corresponding to a total of 537,024 contacts with Eurasian woodcocks and 1,187,292 hours of hunting.

Phenology The model describing variation in relative abundance of Eurasian woodcock by decade (10-day period) explained $26.4 \%$ of the deviance (Table 1 ). The deviance explained corresponds to the unadjusted variance explained by the models. Geographic location and season had a smoothing term significantly different from zero (Table 1), which indicates they have a significant contribution to the model. After a slight decrease during September, relative abundance increased during following decades, from the beginning of October until the first decade of December. From December to the end of February, abundance remained high but decreased slightly over time (non-significant; see Fig. 2). 
Trend The 3 GAMMs describing the variation in relative abundance of Eurasian woodcock between hunting seasons for the entire season, the migration period, and the wintering period described $26.9 \%, 27.7 \%$ and $26.9 \%$ of respective deviance (Table 1). Geographic location and day of the hunting season had a smoothing term significantly different from zero $(P<0.001)$ in all 3 models. There was no evidence of a significant trend in Eurasian woodcock relative abundance during the last 10 years in southwestern Europe (Fig. 3).

\section{DEMOGRAPHY}

Sex For hunting seasons from 2006-2007 through 20152016, sex was determined for 31,604 Eurasian woodcock (Table 2; birds from Ireland and Wales were not sexed). During this period, the proportion of males and females in hunting bags did not vary significantly in the 2 regions considered: Swiss-Franco-Iberian $\left(\chi^{2}=6.555, \mathrm{df}=9\right.$, $P=0.683)$ and Swiss-Italian $\left(\chi^{2}=5.706, \mathrm{df}=6, P=0.457\right)$. The proportion of females was significantly lower in the Swiss-Italian region for all hunting seasons (since 2011-2012).

Age For hunting seasons from 2006-2007 through 2015-2016, age was determined for 135,750 Eurasian woodcock (Table 3). During this period, the proportion of juveniles and adults in hunting bags varied significantly in all regions (Fig. 4): Swiss-Franco-Iberian $\left(\chi^{2}=794.718, \mathrm{df}=9\right.$, $P<0.001)$; Swiss-Italian $\left(\chi^{2}=329.990, \mathrm{df}\right.$ $=6, P<0.001)$; British Isles $\left(\chi^{2}=194.755\right.$, $\mathrm{df}=7, P<0.001)$. Geographic differences in age ratios were consistently observed across hunting seasons (Table 3; Fig. 4): the sample from the Swiss-Italian region always contained higher proportions of juveniles, whereas the British Isles always contained lower proportions. Despite the lack of statistical significance, proportions observed in the Swiss-Franco-Iberian region were strongly correlated with those observed in the Swiss-Italian region $(\mathrm{r}=$ 0.70, $P=0.079)$ and the British Isles $(\mathrm{r}=$ $0.68, P=0.062$ ).

Variation between hunting seasons in the age ratio of Eurasian woodcock shot in Denmark during the period under study is also represented in Fig. 4. Danish values were significantly correlated with those from the Swiss-Italian region ( $\mathrm{r}=0.82, P=0.024$ ), but not with those from the Swiss-Franco-Iberian region $(\mathrm{r}=$ $0.57, P=0.085)$ or the British Isles $(\mathrm{r}=0.10$, $P=0.806)$.

\section{Dicussion}

\section{RELATIVE ABUNDANCE}

We used data collected during hunting activity to indirectly assess the relative abundance of the Eurasian woodcock population, namely the number of different Eurasian woodcock observed during a hunting trip-a number which, unlike the number of woodcock shot, is not influenced by the bag limit that exists in some countries included in our study. Though already possible to examine with other game bird species (e.g., Palmer et al. 2002; Cattadori et al. 2003), the type of relationship between Eurasian woodcock indexes of relative abundance and density is still to be demonstrated. Still, Ferrand et al. (2010) reported a strong correlation between the number of Eurasian woodcock observed per hunting trip and the number observed per hour during nocturnal banding sessions, which the authors considered strong evidence that the relative abundance estimated from hunting is a valid approach for evaluating autumn and winter abundance variation. In our study we accounted for harvesting effort (duration of hunting trip), which may be sufficient to remove some bias on the use of relative abundance to estimate genuine patterns of population change (Botsford et al. 1983, Berryman 1991, Berryman and Turchin 2001). We used data from a specific method of hunting Eurasian woodcock (with pointing dogs) and also accounted for the period within each hunting season, the hunting sea-

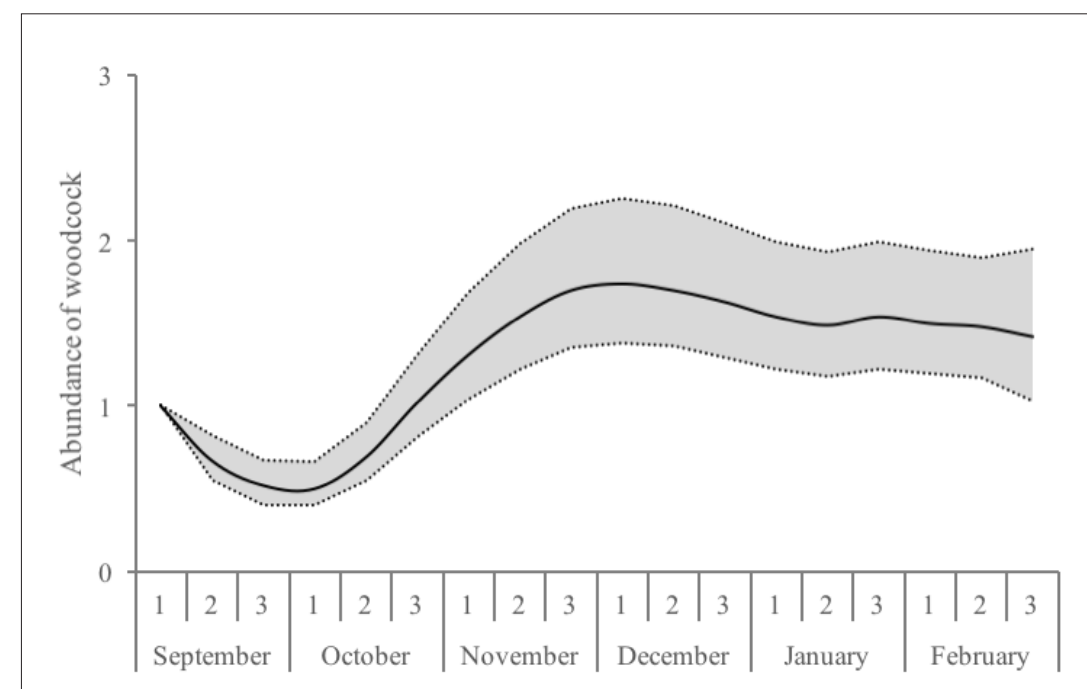

Figure 2. Variation in Eurasian woodcock (Scolopax rusticola) relative abundance by decade (period of 10 days) between September and February in southwestern Europe (France, Spain, and Portugal; hunting seasons 2006-2007 to 2015-2016). The solid line corresponds to the fitted relative abundance from a generalized additive mixed model (GAMM) with $18 \mathrm{df}$. The shaded area represents upper and lower $95 \%$ CI. 
son, and the region. Cattadori et al. (2003, p. 440) note that "one of the strengths of harvesting records is that they often represent samples from a large area of suitable habitat, often over long time periods and with established harvesting traditions that provide good comparable data." We think that our sample presents these properties.

Phenology In the Franco-Iberian region, an area that includes France, Spain, and Portugal, relative abundance of Eurasian woodcock increased from September to the beginning of December, then remained high with only a slight decrease until the end of February. Eurasian woodcock are present year round in part of this region, namely in central, north-eastern, and mountainous areas of France (Ferrand et al. 2008) and in northern Spain (Onru-

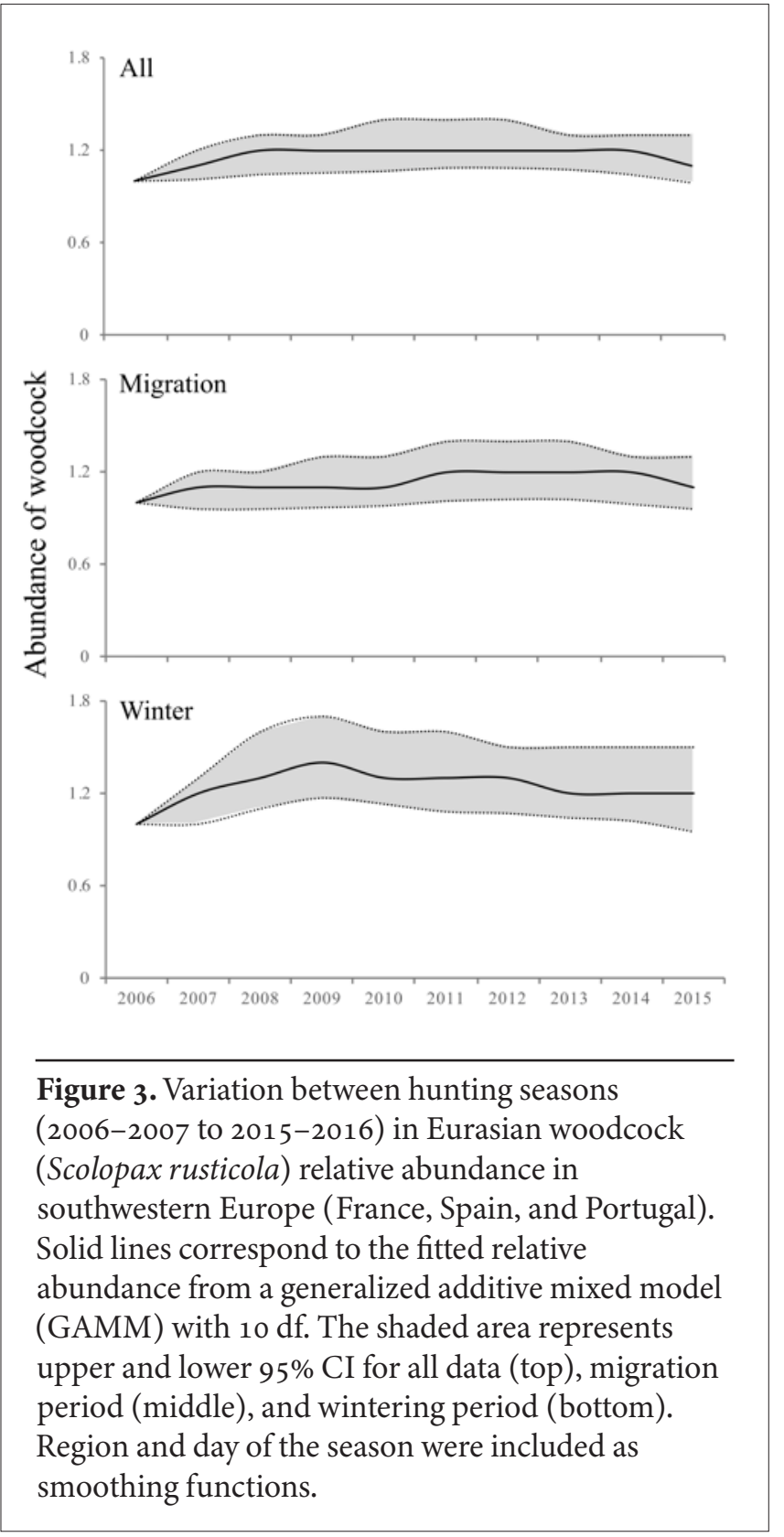

bia 2003), but during autumn and winter they are present over a wider area, including Portugal and southern parts of Spain. Our results show that in southwestern Europe, most migratory Eurasian woodcock arrive before mid-December and do not leave these areas before the end of February.

For birds breeding in the most northern and eastern parts of Europe (Finland, Russia), autumn migration begins at the end of September or at the beginning of October (Iljinsky et al. 200o). General movement in Scandinavia occurs from October to November (Clausager 1974, Christensen and Asferg 2016). Thus, phenology observed in the Franco-Iberian region is in accordance with what would be expected, given its southwestern position in Europe.

The significant contributions of hunting season and region to our models of abundance are the result of differences in autumn migration and winter phenology between hunting seasons and regions. Several authors have already recorded differences in the timing of migration among years (e.g., Clausager 1974, Birtsas et al. 2013, Rodrigues et al. 2013). A 12-year study in Macedonia found that arrival date was related to atmospheric stability, with the onset of autumn migration postponed in warmer autumns (Birtsas et al. 2013).

The small proportion of the deviance explained by the model must be related to the low number of explanatory variables. Models may be improved with collection of additional variables related to each hunter and their dogs, or environmental variables in wintering and breeding areas that may influence habitat selection and migratory movements (Péron et al. 2011, Birtsas et al. 2013).

Trend According to our models describing variation in Eurasian woodcock relative abundance between hunting seasons, abundance during autumn migration and winter in the Franco-Iberian region has remained stable in the last 10 years. As with the phenology model discussed above, these models explained little deviance, and the inclusion of other variables could help improve the model. For instance, previous analysis of Eurasian woodcock hunting data from northern Spain indicated that relative abundance of Eurasian woodcock is related to weather conditions during the previous spring in breeding areas (Guzmán and Arroyo 2015).

A lack of trend was observed in France for the period 1990-1991 to 2002-2003 for several indices of autumn-winter abundance, including the number of Eurasian woodcock seen per 3.5 hours of hunting (Ferrand et al. 2006, 2008), and in northern Spain for the period 1991-1992 to 2011-2012, based upon the number of Eurasian woodcock observed per hour of hunting (Guzmán and Arroyo 2015). The latter study included partial data analyzed in the present paper. In the United Kingdom, the variation between hunting seasons in the number of Eurasian woodcock shot per 100 ha from 1961 to 2004 suggests a stable trend 
over the final 25 years (Aebischer and Harradine 2007). Conversely, in these regions some breeding populations declined during the last decenniums (Hewson and Noble 2009, Heward et al. 2015, Mollet 2015, Mulhauser and Zimmerman 2015). This difference is due to the fact that 2 groups of Eurasian woodcock occur in Western Europe: those that breed and winter there and others that only winter there and originate from western Russia, the Baltic States, Fennoscandia, and Central Europe (Bauthian et al. 2007; Guzmán et al. 2011; Hobson et al. 2013a,b; Hoodless et al. 2013; Arizaga et al. 2014). In France and Spain the latter represent ca. $90 \%$ of the Eurasian woodcock harvested (Hobson et al. 2013a,b), similar to values reported for the British Isles (Hoodless et al. 2013). Thus, by collecting data during autumn-winter (hunting season) in Western Europe, we are able to monitor not only the population that breeds there, but also a significant portion of the large population that breeds farther north and east. The meteorological conditions registered during the breeding season in the Baltic region are related to the winter relative abundance of Eurasian woodcock in northern Spain (Guzmán and Arroyo 2015), and winter relative abundance in France is strongly correlated with the proportion of chicks that have undergone complete molt at the end of summer in Russia (Ferrand and Gossmann 2009b). It is possible to use all this information to predict annual relative abundance during the hunting season in Western Europe, at least in the Franco-Iberian region (Ferrand and Gossmann 2009b, Guzmán and Arroyo 2015).

\section{DEMOGRAPHY}

Sex The proportion of males and females in the Eurasian woodcock hunting bags remained stable in the Swiss-Franco-Iberian and Swiss-Italian regions during the period of our study, but the first region presented a higher proportion of females. This was previously recorded in hunting bag results published for France and Italy in the 1970s and 1980s (Spanò and Ghelini 1983, Fadat 1988).

The Eurasian woodcock hunting method most commonly used in both regions is the same-hunting with pointing dogs-and this could partially explain the tendency for hunting bags to contain more females than males, as females seem to seek more temperate and humid habitats, and hunters, knowing that they will find higher Eurasian woodcock numbers in such areas, visit them preferentially (Fadat 1988, 1995). Another factor that can contribute to higher proportions of females is the differential migration that seems to characterize Eurasian woodcock, i.e., females leave breeding areas earlier in autumn and arrive at breeding areas in spring later than males; females are therefore exposed to longer periods of hunting susceptibility during the non-breeding season compared to males (Clausager 1974; Fadat 1981, 1989; Fokin and Blokhin 2000; Ferrand et al. 2013). Additionally, Christensen et al. (2017) proposed that males may stay farther north in Europe than females during autumn and winter. The higher proportion of females in the Swiss-Franco-Iberian region could, eventually, be due to the region's great distance from the core breeding area of the majority of Eurasian woodcock that winter there.

Age The proportion of juveniles to adults varied over the period of our study and among the regions we considered. Although the proportion of juveniles is considered a practical measure of breeding success in waders (Minton 2003), the relationship is not direct. The proportion of juveniles among Eurasian woodcock shot during the hunting season can also be influenced by several other factors (Harradine 1983, 1988; Fadat, 1981, 1988, 1995). The breeding areas for most of the wintering Eurasian woodcock analyzed are very large and diverse (from Western Europe to western Siberia); both within and between seasons there is likely to be variation in production of fledged juveniles from one part of the range to another (Harradine 1983). Hunting pressure also has been demonstrated to influence age ratio (Fadat 1981, Duriez et al. 2005a, Péron et al. 2012). Adult Eurasian woodcock tend to occupy the best sites within wintering areas and are very faithful to them between winters, removal by hunting promotes more frequent replacement by juvenile Eurasian wood-

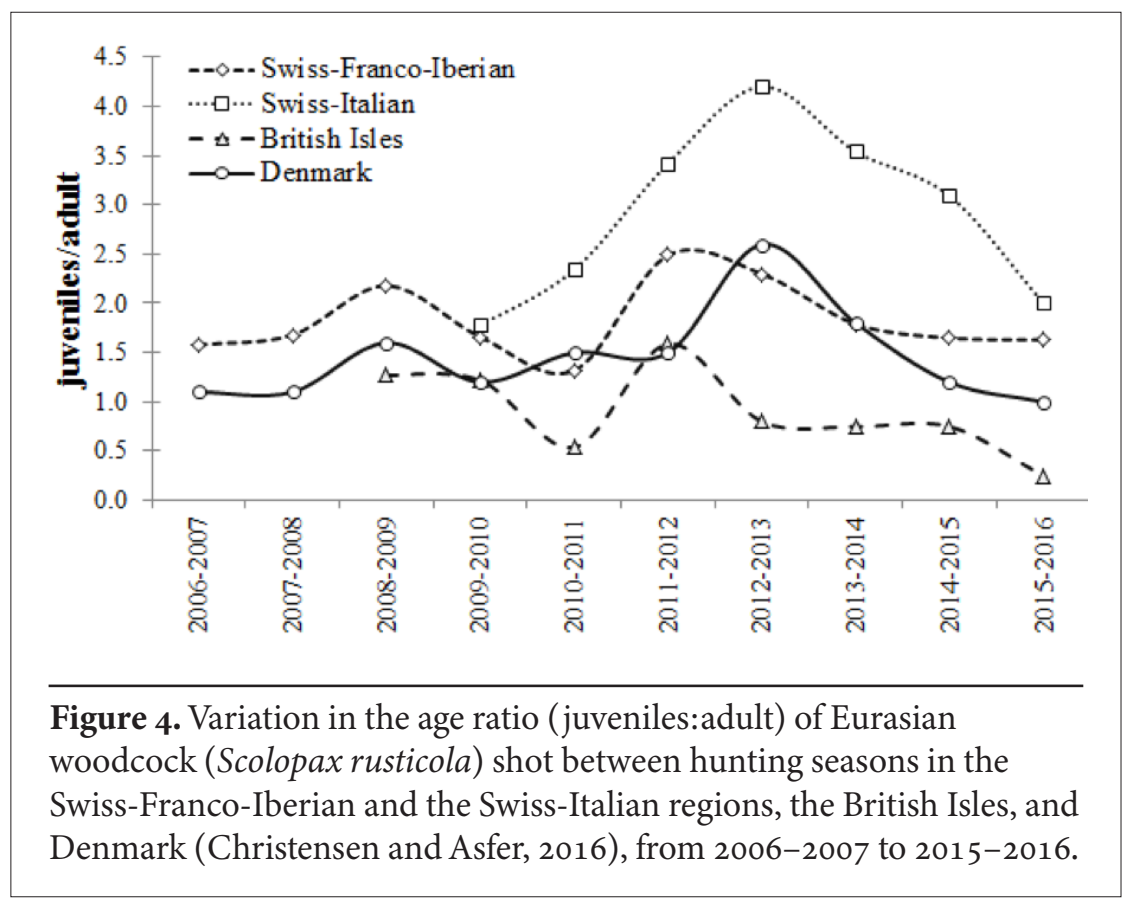


cock, and higher hunting pressure can therefore lead to higher proportions of juvenile Eurasian woodcock. Also, distribution of juveniles may be influenced by weather conditions during autumn migration and movements in response to inclement-weather conditions that occur in some winters (Ferrand et al. 2008).

To overcome possible biases caused by these factors, Ferrand et al. (2008) proposed that the age ratio must be estimated for the maximum number of wintering areas possible. In the present study we analyzed the variation in the proportion of juveniles over most of southwestern Europe. Concerning hunting pressure, providing that it remains fairly constant from year to year within a country or region, there is no reason why it should obscure major variations between years in the proportion of juveniles in the population (Hirons 1988b).

Geographic differences in age ratios observed each season in hunting bags correspond, in general, to those described in previous works (Fadat 1988, 1995; Harradine 1983, 1988; Ferrand et al. 2008). The British Isles tend to present lower values. The hunting method (driven shooting is more prevalent) and the lower mortality estimated (Hoodless and Coulson 1994; Tavecchia et al. 2002; Péron et al. 2012) may partially explain differences between the British Isles and the Swiss-Franco-Iberian and the Swiss-Italian regions. However, we must take into account that our sample size for the British Isles, mainly since the
2009-2010 hunting season, is small. Additionally, Ireland and Wales only represent a part of the British Isles and age ratio seems to vary within this region (Harradine 1983, 1988).

\section{Acknowledgments}

We would like to thank all hunters for providing Eurasian woodcock hunting data to their national clubs or associations, which made this study possible. We thank A. Múrias dos Santos for granting us access to computational facilities. We also thank Shaun Oldenburger and 2 anonymous referees for their comments on the manuscript.

\section{Literature Cited}

Aebischer, N.J., and J. Harradine. 2007. Developing a tool for improving bag data of huntable birds and other bird species in the UK. Research Report, The Game Conservancy Trust, Hampshire, and British Association for Shooting and Conservation, Wrexham, United Kingdom.

Arizaga, J., A. Crespo, I. Telletxea, R. Ibáñez, F. Díez, J.F. Tobar, M. Minondo, Z. Ibarrola, J.J. Fuente, and J.A. Pérez. 2014. Solar/ Argos PTTs contradict ring-recovery analyses: woodcocks wintering in Spain are found to breed further east than previously stated. Journal of Ornithology 156:515-523.

Bauthian, I., F. Grossmann, Y. Ferrand, and R. Julliard. 2007. Quantifying the origin of woodcock wintering in France. Journal of Wildlife Management 71:701-705.

Berryman, A.A., 1991. Can economic forces cause ecological chaos? The case of the northern California Dungeness crab fishery. Oikos 62:106-109.

Table 3. Variation among hunting seasons (2006-2007 to 2015-2016) in the age ratio (juveniles/adult) of Eurasian woodcock (Scolopax rusticola) shot in each region studied. n: sample size; Chi-square test $\left(\chi^{2}\right)$ results comparing frequencies of age classes among regions (all values correspond to $P<0.001$ ).

\begin{tabular}{|c|c|c|c|c|c|c|c|}
\hline \multirow{3}{*}{$\begin{array}{l}\text { Hunting } \\
\text { season }\end{array}$} & \multicolumn{6}{|c|}{ Region } & \multirow[b]{3}{*}{$\chi^{2}$} \\
\hline & \multicolumn{2}{|c|}{$\begin{array}{c}\text { Swiss-Franco-Iberian } \\
\text { Switzerland }^{\mathrm{a}}+\text { France }^{\mathrm{b}}+ \\
\text { Spain + Portugal }\end{array}$} & \multicolumn{2}{|c|}{$\begin{array}{c}\text { Swiss-Italian } \\
\text { Switzerland }^{\mathrm{d}}+\text { Italy }^{\mathrm{e}}\end{array}$} & \multicolumn{2}{|c|}{$\begin{array}{c}\text { British Isles } \\
\text { Ireland + Wales }\end{array}$} & \\
\hline & Juveniles:adult & $n$ & Juveniles:adult & $n$ & Juveniles:adult & $n$ & \\
\hline $2006-2007$ & 1.58 & 9,970 & & & & & \\
\hline $2007-2008$ & 1.68 & 11,117 & & & & & \\
\hline $2008-2009$ & 2.18 & 10,998 & & & 1.27 & 1,407 & 88.52 \\
\hline $2009-2010$ & 1.66 & 11,690 & 1.78 & 1,000 & 1.22 & 1,218 & 27.55 \\
\hline $2010-2011$ & 1.32 & 9,662 & 2.34 & 1,018 & 0.54 & 692 & 207.11 \\
\hline $2011-2012$ & 2.49 & 10,660 & 3.42 & 2,143 & 1.59 & 556 & 64.22 \\
\hline $2012-2013$ & 2.30 & 10,567 & 4.20 & 3,679 & 0.80 & 998 & 520.78 \\
\hline $2013-2014$ & 1.79 & 11,496 & 3.54 & 3,967 & 0.75 & 339 & 350.35 \\
\hline $2014-2015$ & 1.65 & 11,232 & 3.09 & 4,688 & 0.75 & 493 & 376.39 \\
\hline $2015-2016$ & 1.63 & 11,390 & 2.00 & 4,651 & 0.25 & 119 & 125.74 \\
\hline Total & & 108,782 & & 21,146 & & 5,822 & \\
\hline
\end{tabular}

a only cantons from Romandie; ${ }^{\mathrm{b}}$ excluding Corsica; ${ }^{\mathrm{c}}$ since 2009-2010; $d$ only Ticino; $e$ excluding Sardinia and Sicilia 
Berryman, A., and P. Turchin. 2001. Identifying the density-dependence structure underlying ecological time series. Oikos 92:265-270.

BirdLife International. 2015. European Red List of Birds. Office for Official Publications of the European Communities, Luxembourg.

BirdLife International. 2016. Scolopax rusticola. The IUCN Red List of Threatened Species 2016: e.T22693052A86627978. <http://dx. doi.org/10.2305/IUCN.UK.2016-3.RLTS.T22693052A86627978. en $>$. Accessed o1 September 2017.

Birtsas, P., C. Sokos, K.G. Papaspyropoulos, T. Batselas, G. Valiakos, and C. Billins. 2013. Abiotic factors and autumn migration phenology of woodcock (Scolopax rusticola Linnaeus, 1758, Charadriiformes: Scolopacidae) in a Mediterranean area. Italian Journal of Zoology 80:392-401.

Blokhin, Y., A. Solokha, K. Gorokhowsky, A. Mezhnev, and S. Fokin. 2015. Hunting bags of woodcock, snipes and other waders in Russia. Wetlands International/IUCN - Woodcock and Snipe Specialist Group Newsletter 41:13-18.

Boidot, J.-P., J.-F. Cau, and G. Aurousseau. 2015. Evaluation of the 2014/15 woodcock hunting season in France. Wetlands International/IUCN - Woodcock and Snipe Specialist Group Newsletter 41:49-50.

Botsford, L.W., R.D. Methot Jr, and W.E. Johnston. 1983. Effort dynamics of the northern California dungeness crab (Cancer magister) fishery. Canadian Journal of Fishery and Aquatic Sciences 40:337-346.

Cattadori, I.M., D.T. Haydon, S.J. Thirgood, and P.J. Hudson. 2003. Are indirect measures of abundance a useful index of population density? The case of red grouse harvesting. Oikos 10o:439-446.

Christensen, T.K. 2017. Danish Wing Survey and hunting bag. $<$ http://fauna.au.dk/en/jagt-og-vildtforvaltning/danish-wingsurvey-and-hunting-bag/>. Accessed 10 Nov 2017.

Christensen, T.K., and T. Asferg. 2016. Woodcock hunting in Denmark 2015/16. Wetlands International/IUCN - Woodcock and Snipe Specialist Group Newsletter 42:5-6.

Christensen, T.K., A.D. Fox, P. Sunde, and J.P. Hounisen, and L.W. Andersen. 2017. Seasonal variation in the sex and age composition of the woodcock bag in Denmark. European Journal of Wildlife Research 63:52.

Clausager, I. 1974. Migration of Scandinavian woodcock (Scolopax rusticola) with special reference to Denmark. Danish Review of Game Biology 8:38.

Cramp, S., and K.E.L. Simmons, editors. 1983. Handbook of the birds of Europe, the Middle East and North Africa: the birds of the Western Palearctic. Volume 3. Oxford University Press, Oxford, United Kingdom.

Duriez, O., C. Eraud, C. Barbraud, and Y. Ferrand. 2005a. Factors affecting population dynamics of Eurasian woodcocks wintering in France: assessing the efficiency of a hunting-free reserve. Biological Conservation 122:89-97.

Duriez, O., Y. Ferrand, F. Binet, E. Corda, F. Gossmann, and H. Fritz. 2005 b. Habitat selection of the Eurasian woodcock in winter in relation to earthworms availability. Biological Conservation 122:479-490.

Fadat, C. 1979. Estimation des variations relatives de densités de bécasses (Scolopax rusticola) par la méthode des indices cynégétiques d'abondance (ICA). Bulletin mensuel de l'Office national de la chasse Numéro Spécial Scientifique et Technique Décembre. 1979:71-110. [In French.]

Fadat, C. 1981. Age-ratio des tableaux de chasse de bécasses (Scolopax rusticola). Signification biologique et utilisation pour la bonne gestion des populations bécassières. Bulletin mensuel de l'Office national de la chasse Numéro Spécial Scientifique et Technique, Novembre 1981:141-172. [In French.]

Fadat, C. 1988 Utilisation des tableaux de bécasses (Scolopax rusticola) pour ala géstion cynégétique de leurs populations. Pages
96-107 in P. Havet, and G. Hirons, editors. Third European Woodcock and Snipe Workshop - Proceedings, Paris, Office National de la Chasse, International Waterfowl Research Bureau, Conseil international de la chasse, St-Just-La-Pendue, France. [In French.]

Fadat, C. 1989. Modalités zoogéographiques de la migration et de l'hivernage en France de la bécasse des bois (Scolopax rusticola L.) et gestion cynégétique de ses populations. 3 tomes. Dissertation, Université des sciences et techniques du Languedoc, Montpellier, France. [In French.]

Fadat, C. 1995. La bécasse des bois en hiver: Écologie, Chasse, Gestion. Empremieries Maury, Clermont-l'Hérault, France [in French.]

Faragó, S., R. László, D. Fluck, A. Bende. 2013. Analyses of sex and age ratios of the woodcock population shot in spring 2010 in Hungary. Pages 53-56 in Y. Ferrand, editor. Seventh European Woodcock and Snipe Workshop - Proceedings of an International Symposium of the IUCN/Wetlands International Woodcock \& Snipe Specialist Group. Office National de la Chasse et de la Faune Sauvage, Paris, France.

Ferrand, Y. 1989. Contribution à l'étude du comportement du mâle de Bécasse des Bois Scolopax rusticola L. en période de reproduction. Méthode de dénombrement. Dissertation, University of Montpellier, Montpellier, France. [In French.]

Ferrand, Y. 1993. A census method for roding Eurasian woodcock in France. Pages 19-25 in J.R. Longcore, and G.F. Supik, editors. Proceedings of the Eighth American Woodcock Symposium. U.S. Fish and Wildlife Service Biological Report 16, Washington, D.C., USA.

Ferrand, Y., P. Aubry, F. Gossmann, C. Bastat, and M. Guénézan. 2010. Monitoring of the European woodcock populations, with special reference to France. Pages 37-44 in C.A. Stewart, and V.R. Frawley, editors. Proceedings of the Tenth American Woodcock Symposium. Michigan Department of Natural Resources and Environment, Roscommon, Michigan, USA.

Ferrand, Y., P. Aubry, P. Landry, and P. Priol. 2013. Responses of Eurasian woodcock Scolopax rusticola to simulated hunting disturbance. Wildlife Biology 19:19-29

Ferrand, Y., and F. Gossmann. 2001. Elements for a woodcock (Scolopax rusticola) management plan. Game and Wildlife Science 18:115-139.

Ferrand, Y., and F. Gossmann. 2009a. Ageing and sexing series 5: ageing and sexing the Eurasian woodcock Scolopax rusticola. Wader Study Group Bulletin 116:75-79.

Ferrand, Y., and F. Gossmann. 2009b. La Bécasse des Bois. Histoire naturelle. Effet de Lisières, Saint Lucien, France. [In French.]

Ferrand, Y., F. Gossmann, C. Bastat, and M. Guénézan. 2006. What census method for migrating and wintering woodcock populations? Pages 37-43 in Y. Ferrand, editor. Sixth European Woodcock and Snipe Workshop - Proceedings of an International Symposium of the Wetlands International Woodcock and Snipe Specialist Group. International Wader Studies 13, Wageningen, The Netherlands.

Ferrand, Y., F. Gossmann, C. Bastat, and M. Guénézan. 2008. Monitoring of the wintering and breeding woodcock populations in France. Revista Catalana d'Ornitologia 24:44-52.

Ferrand, Y., K. Le Rest, F. Gossmann, and P. Aubry. 2017. Estimation du tableau de chasse de la bécasse des bois en France pour la saison 2013-2014. Faune sauvage 315:9-14 [In French.]

Fokin, S., and Y. Blokhin. 20oo. Roding activity, spring hunting and hunting bags of woodcock (Scolopax rusticola) in Russia. Pages 19-24 in H. Kalchreuter, editor. Fifth European Woodcock and Snipe Workshop - Proceedings of an International Symposium of the Wetlands International Woodcock \& Snipe Specialist Group. Wetlands International Global Series No. 4, and International Wader Studies 11, Wageningen, The Netherlands. 
Gossmann, F., S. Fokin, I. Iljinski. 200o. Ringing of woodcock in Russia from 1991 to 1997. Pages 10-14 in H. Kalchreuter, editor. Fifth European Woodcock and Snipe Workshop - Proceedings of an International Symposium of the Wetlands International Woodcock and Snipe Specialist Group. Wetlands International Global Series No. 4, and International Wader Studies 11, Wageningen, The Nehterlands.

Gossmann, F., Y. Ferrand, Y. Loidon, and G. Sardet. 1988. Méthodes et résultats de baguages dés Bécasses des bois (Scolopax rusticola) en Bretagne. Pages 34-41 in P. Havet, and G. Hirons, editors. Third European Woodcock and Snipe Workshop - Proceedings, Paris, Office National de la Chasse, International Waterfowl Research Bureau, Conseil international de la chasse, St-Just-LaPendue, France. [In French.]

Guzmán J.L., Y. Ferrand, and B. Arroyo. 2011. Origin and migration of woodcock Scolopax rusticola wintering in Spain. European Journal of Wildlife Research 57:647-655.

Guzmán, J.L., and B. Arroyo. 2015. Predicting winter abundance of woodcock Scolopax rusticola using weather data: implications for hunting management. European Journal of Wildlife Research 61:467-474. Harradine, J. 1983. The Woodcock Production Survey in Great Britain. Pages 100-117 in H. Kalchreuter, editor. Second European Woodcock and Snipe Workshop - Proceedings. International Waterfowl Research Bureau, Slimbridge, Glos, England.

Harradine, J. 1988. The Woodcock Production Survey in the United Kingdom and Ireland. Pages 87-91 in P. Havet, and G. Hirons, editors. Third European Woodcock and Snipe Workshop Proceedings, Paris, Office National de la Chasse, International Waterfowl Research Bureau, Conseil international de la chasse, St-Just-La-Pendue, France.

Heward, C.J., A.N. Hoodless, G.J. Conway, N.J. Aebischer, S. Gillings, and R.J. Fuller. 2015. Current status and recent trend of the Eurasian woodcock Scolopax rusticola as a breeding bird in Britain. Bird Study 62:535-551.

Hewson, C.M., and D.G. Noble. 2009. Population trends of breeding birds in British woodlands over a 32-year period: relationships with food, habitat use and migratory behaviour. Ibis 151:464-486.

Hirons, G., and P. Bickford-Smith. 1983. The diet and behaviour of Eurasian woodcock wintering in Cornwall. Pages 11-17 in H. Kalchreuter, editor. Second European Woodcock and Snipe Workshop - Proceedings. International Waterfowl Research Bureau, Slimbridge, Glos, England.

Hirons, G., and T.H. Johnson. 1987. A quantitative analysis of habitat preferences of woodcock Scolopax rusticola in the breeding season. Ibis 129:371-381.

Hirons, G. 1987. Habitat use by woodcock Scolopax rusticola during the breeding season. Gibier Faune Sauvage 4:349-362.

Hirons, G. 1988a. Habitat use by woodcock (Scolopax rusticola) during the breeding season. Pages 42-47 in P. Havet, and G. Hirons, editors. Third European Woodcock and Snipe Workshop - Proceedings, Paris, Office National de la Chasse, International Waterfowl Research Bureau, Conseil international de la chasse, St-Just-La-Pendue, France.

Hirons, G. 1988b. Some factors affecting age ratios among woodcock wings collected from hunters in Britain. Pages 92-95 in P. Havet, and G. Hirons, editors. Third European Woodcock and Snipe Workshop - Proceedings, Paris, Office National de la Chasse, International Waterfowl Research Bureau, Conseil international de la chasse, St-Just-La-Pendue, France.

Hirschfeld, A., and A. Heyd. 2005. Mortality of migratory birds caused by hunting in Europe: bag statistics and proposals for the conservation of birds and animal welfare. Berichte zum Vogelschutz 42:47-74.

Hobson, K.A., S.L. van Wilgenburg, Y. Ferrand, F. Gossman, and C. Bastat. 2013a. A stable isotope $\left(\delta_{2} \mathrm{H}\right)$ approach to deriving ori- gins of harvested woodcock (Scolopax rusticola) taken in France. European Journal of Wildlife Research 59:881-892.

Hobson, K.A., S.L. van Wilgenburg, J.L. Guzmán, and B. Arroyo. 2013b. Origins of juvenile woodcock (Scolopax rusticola) harvested in Spain inferred from stable hydrogen isotope $\left(\delta_{2} \mathrm{H}\right)$ analyses of feathers. Journal of Ornithology 154:1087-1094.

Hoodless, A.N., and J.C. Coulson. 1994. Survival rates and movements of British and continental woodcock Scolopax rusticola in the British-Isles. Bird Study 41:48-60.

Hoodless, A.N., J.G. Inglis, J.P. Doucet, and N.J. Aebischer. 2008. Vocal individuality in the roding calls of woodcock Scolopax rusticola and their use to validate a survey method. Ibis 150:80-89.

Hoodless, A.N., A. Powell, Y. Ferrand, A.G. Gosler, J. Fox, J. Newton, and O. Williams. 2013. Application of new technologies to the study of Eurasian woodcock migration. Pages 29-35 in Y. Ferrand, editor. Seventh European Woodcock and Snipe Workshop - Proceedings of an International Symposium of the IUCN/Wetlands International Woodcock \& Snipe Specialist Group. Office National de la Chasse et de la Faune Sauvage, Paris, France.

Iljinsky, I.V., S.A. Fetisov, V.G. Ptschelinzev, M.V. Verevkin, V.I. Golovan, D.V. Chistyakov, and F. Gossmann. 200o. First results of woodcock (Scolopax rusticola) ringing in the north-west regions of Russia. Pages 15-18 in H. Kalchreuter, editor. Fifth European Woodcock and Snipe Workshop - Proceedings of an International Symposium of the Wetlands International Woodcock \& Snipe Specialist Group. Wetlands International Global Series No. 4, and International Wader Studies 11, Wageningen, The Netherlands.

Knape, J. 2016. Decomposing trends in Swedish bird populations using generalized additive mixed models. Journal of Applied Ecology 53:1852-1861.

Meunier, B., J.-F. Cau, and J.M. Desbieys. 2016. Evaluation of the 2015/16 woodcock hunting season in France. Wetlands International/IUCN - Woodcock and Snipe Specialist Group Newsletter 42:39-40.

Minton, C. 2003. The importance of long-term monitoring of reproduction rates in waders. Wader Study Group Bulletin 100:178-182.

Mollet, P. 2015. La bécasse des bois (Scolopax rusticola) en Suisse Synthèse 2014. Station Ornithologique Suisse, Sempach, Switzerland. [In French.]

Mulhauser, B., and J.-L. Zimmermann. 2015. Suivi démographique de la Bécasse des bois Scolopax rusticola en période de reproduction dans le canton de Neuchâtel (Suisse) entre 2001 et 2010. Aves 52:129-150. [In French.]

Nagy, S., S. Flink, and T. Langendoen. 2015. Report on the conservation status of migratory waterbirds in the Agreement Area. Sixth edition. - Document from the 6th meeting of the parties under the Agreement on the Conservation of African-Eurasian Migratory Waterbirds, Bonn, Germany.

Onrubia, A. 2003. Chocha Perdiz, Scolopax rusticola. Pages: 258-259 in R. Martí, and J.C. del Moral, editors. Atlas de las Aves Reproductoras de España. Dirección General de Conservación de la Naturaleza - Sociedad Española de Ornitología, Madrid, Spain. [In Spanish.]

Palmer, W.E., S.D. Wellendorf, L.A. Brennan, W.R. Davidson, and F.E. Kellogg. 2002. Hunting success and northern bobwhite density on Tall Timbers Research Station: 1970-2001. Pages 213-216 in S.J. DeMaso, W.P. Kuvlesky, Jr., F. Hernández, and M.E. Berger, editors. Quail V: Proceedings of the Fifth National Quail Symposium. Texas Parks and Wildlife Department, Austin, Texas, USA.

Péron, G., Y. Ferrand, R. Choquet, R. Pradel, F. Gossmann, C. Bastat, M. Guénézan, I. Bauthian, R. Julliard, and O. Gimenez. 2012. Spatial heterogeneity in mortality and its impact on the population dynamics of Eurasian woodcocks. Population Ecology 54:305-312. 
Péron, G., Y. Ferrand, F. Gossmann, C. Bastat, M. Guénézan, and O. Gimenezet. 2011. Escape migration decisions in Eurasian woodcocks: insights from survival analyses using large-scale recovery data. Behavioral Ecology and Sociobiology 65:1949-1955.

R Core Team. 2016. R: A Language and Environment for Statistical Computing. Vienna: R Foundation for Statistical Computing.

Rodrigues, T., D. Gonçalves, A. Verde, and M. Russo. 2013. The woodcock in mainland Portugal: results of four hunting seasons monitoring. Wetlands International/IUCN - Woodcock and Snipe Specialist Group Newsletter 39:42-46.

Snow, D.W., and Perrins, C.M., editors. 1998. The birds of the western Palearctic (Concise Edition): Volume 1 Non-Passerines. Oxford University Press, Oxford, United Kingdom.

Spanò, S., and A. Ghelini. 1983. Some results of a five years study on woodcock in Italy. Pages 127-131 in H. Kalchreuter, editor. Second European Woodcock and Snipe Workshop - Proceedings. International Waterfowl Research Bureau, Slimbridge, Glos, England.

Tavecchia, G., R. Pradel, F. Gossmann, C. Bastat, Y. Ferrand, and J.-D. Lebreton. 2002. Temporal variation in annual survival probability of the Eurasian woodcock Scolopax rusticola wintering in France. Wildlife Biology 8:21-30.

Van Gils, J., P. Wiersma, and G.M. Kirwan. 2015. Eurasian woodcock (Scolopax rusticola). in J. del Hoyo, A. Elliott, J. Sargatal, D.A. Christie, and E. de Juana, editors. Handbook of the Birds of the World Alive. Lynx Edicions, Barcelona, Spain. <http://www.hbw. com/node/53860> Accessed 18 Dec 2015.

Wetlands International. 2017. Waterbird Population Estimates. $<$ wpe. wetlands.org $>$ Accessed 11 Oct 2017.

Wilson, J. 1983. Wintering site fidelity of woodcock in Ireland. Pages 18-27 in H. Kalchreuter, editor. Second European Woodcock and Snipe Workshop - Proceedings. International Waterfowl Research Bureau, Slimbridge, Glos, England.

Wood, S.N. 2011. Fast stable restricted maximum likelihood and marginal likelihood estimation of semiparametric generalized linear models. Journal of the Royal Statistical Society (B) 73:3-36.

Zuur, A.F. 2012. Beginner's guide to generalized additive models with R. Highland Statistics Ltd, Newburgh, United Kingdom.

Appendix A. Features of the 2015-2016 Eurasian woodcock hunting season by country member of FANBPO and respective regions (when justified), namely on the start and ending dates, the number of days per week hunting is allowed, the existence of a daily or seasonal bag limit (number of Eurasian woodcock allowed to be shot per hunter, daily or seasonally; also known as PMA - Prélèvement Maximal Autorisé or Maximum Authorized Harvesting). In the last decade these features remained relatively constant.

\begin{tabular}{|c|c|c|c|c|c|c|c|}
\hline \multirow[b]{2}{*}{ Country } & \multirow[b]{2}{*}{ Region } & \multirow[b]{2}{*}{ Start } & \multirow[b]{2}{*}{ End } & \multirow{2}{*}{$\begin{array}{l}\text { Days/ } \\
\text { Week }\end{array}$} & \multicolumn{3}{|c|}{ Bag limit } \\
\hline & & & & & daily & weekly & seasonally \\
\hline Ireland & & $01-11-2015$ & $31-01-2016$ & 7 & $\mathrm{NO}$ & & $\mathrm{NO}$ \\
\hline Wales & & $01-10-2015$ & $31-01-2016$ & 6 & $\mathrm{NO}$ & & $\mathrm{NO}$ \\
\hline France & & $14-09-2015$ & $20-02-2016$ & $2-7$ & $1-4^{\star}$ & $1-6^{\star}$ & 30 \\
\hline \multirow{2}{*}{ Switzerland } & Romandie & $15-09-2015$ & $14-12-2015$ & $4-6$ & 2 & & $12-20$ \\
\hline & Ticino & $16-10-2015$ & $30-11-2015$ & & & & 15 \\
\hline \multirow[b]{2}{*}{ Italy } & Mainland & $21-09-2015$ & $31-01-2016$ & 3 & $2-3$ & & $15-20$ \\
\hline & $\begin{array}{l}\text { Sardinia and } \\
\text { Sicily }\end{array}$ & 28-09-2015 & 31-01-2016 & 3 & 3 & & 20 \\
\hline \multirow{3}{*}{ Spain } & Mainland & $08-10-2015$ & $15-02-2016$ & $2-7$ & $2-3$ & & $\mathrm{NO}$ \\
\hline & Balearic Islands & $05-10-2015$ & $01-02-2016$ & $2-4$ & $1-4$ & & $\mathrm{NO}$ \\
\hline & Ceuta & $05-10-2015$ & $21-12-2015$ & 3 & & & \\
\hline Portugal & Mainland & $01-11-2015$ & $10-02-2016$ & $2-4$ & 3 & & $\mathrm{NO}$ \\
\hline
\end{tabular}

